IQTISHODUNA

Vol. 16 (1), 2020

P-ISSN: 1829-524X, E-ISSN: 2614-3437

\title{
Pengaruh Motivasi Wirausaha dan Mental Wirausaha terhadap Minat Wirausaha
}

\author{
Bayu Ilham Pradana1, Rini Safitri ${ }^{2 *}$ \\ 1Fakultas Ekonomi Universitas Brawijaya Malang, Indonesia \\ 2Fakultas Ekonomi UIN Maulana Malik Ibrahim Malang, Indonesia
}

\author{
$\Xi$ Corresponding Author: \\ Nama Penulis: Rini Safitri \\ E-mail: rini.safitri@uin-malang.ac.id
}

\begin{abstract}
Indonesia is the lowest entrepreneurial climate in the world based on The Ernest and Young G20 Entrepreneurship Barometer 2013. The number of micros, small and medium enterprises has indeed increased from 2010 to 2015, but when viewed from the growth number shows the opposite. This is due to failure in entrepreneurship, with many factors causing it, one of which is mental entrepreneurship. This study entered the explanatory research category by collecting data using questionnaires. Then the data is processed using PLS, then the results are analyzed. The results of this study indicate that entrepreneurial mentality mediates the influence of entrepreneurial motivation on entrepreneurial interests. Thus it can be interpreted that with the increasing entrepreneurial mentality, the business interests of the students of the UB Entrepreneurship S1 Faculty of Economics and Business Study Program are also getting higher.
\end{abstract}

Keywords: Entrepreneurial mentality, entrepreneurial motivation, entrepreneurial interest.

\begin{abstract}
Abstrak : Indonesia merupakan negara yang memiliki iklim kewirausahaan terendah di dunia berdasarkan The Ernest and Young G20 Entrepreneurship Barometer 2013. Jumlah usaha mikro, kecil dan menengah memang meningkat dari 2010 hingga 2015, tetapi jika dilihat dari angka pertumbuhan menunjukkan sebaliknya. Hal ini disebabkan oleh kegagalan dalam berwirausaha, dengan banyak faktor yang menyebabkannya, salah satunya adalah kewirausahaan mental. Penelitian ini masuk kategori penelitian eksplanatori dengan pengumpulkan data menggunakan kuesioner. Data diolah menggunakan PLS, selanjutnya hasilnya dianalisis. Hasil penelitian ini menunjukkan bahwa mental kewirausahaan memediasi pengaruh motivasi wirausaha terhadap minat wirausaha. Dengan demikian dapat diartikan bahwa dengan meningkatnya mental kewirausahaan, minat bisnis mahasiswa Program Studi S1 Kewirausahaan UB Fakultas Ekonomi dan Bisnis juga semakin tinggi.
\end{abstract}

Kata kunci: Mental wirausaha, motivasi wirausaha, minat wirausaha. 


\section{Cara mencitasi:}

Pradana, B.I., Safitri, R. (2020). Pengaruh Motivasi Wirausaha dan Mental Wirausaha terhadap Minat Wirausaha. Iqtishoduna. Vol. 16 (1): pp 73-82.

\section{Pendahuluan}

Indonesia masuk kategori negara dengan iklim wirausaha paling rendah di dunia Berdasarkan The Ernest and Young G20 Entrepreneurship Barometer 2013, iklim wirausaha di Indonesia dikategorikan paling rendah di dunia (Republika, 2014). Presentase pengusaha di Indonesia saat ini baru mencapai $1,5 \%$ atau sekitar 252 juta penduduk Tanah Air. Indonesia dinyatakan masih membutuhkan sekitar 1,7 juta pengusaha untuk mencapai angka dua persen (Rokhimah., Margunani, 2017).

Jika melihat data UMKM yang tumbuh dari tahun 2005 hingga 2010, pertumbuhan UMKM di Indonesia memang mengalami peningkatan. Namun jika dilihat dari persentase pertumbuhannya, jumlah UMKM mengalami penurunan setiap tahunnya. Hal tersebut disebabkan perkembangan UMKM tidak diiringi dengan perbaikan pengelolaan dan manajemen yang baik, sehingga sering kali sektor ini mengalami kegagalan dan tidak berlangsung lama. Faktor utama adalah lemahnya daya saing dan rendahnya mentalitas wirausahawan baru, yang pada umumnya mereka takut gagal dalam memulai usaha.

Menjadi seorang wirausaha tidaklah terlahir namun dapat dilatih. Salah satu tempat untuk melatih atau mendidik seseorang menjadi seorang wirausaha adalah perguruan tinggi. Namun sayangnya, seringkali mereka lebih memilih untuk mencari kerja daripada membangun usaha dengan alasan takut gagal dan sebagainya. Padahal cita-cita dan semangat untuk menjadi seorang wirausaha terus digaungkan oleh Universitas Brawijaya yang sejalan dengan misi universitas, menjadikan manusia yang berjiwa atau berkemampuan entrepreneur.

Cita-cita dan semangat saja tidak cukup untuk menjadikan seseorang menjadi entrepreneur diperlukan juga pengetahuan dan arahan yang jelas. Megginson dalam Alma (2007) menyatakan beberapa penyebab kegagalan 
dalam small business adalah: (1) Lack of capital, kekurangan modal, tidak bisa menjalin relasi, (2) No business knowledge, kurang memiliki pengetahuan tentang bisnis, (3) Poor management, tidak memiliki keterampilan dalam manajemen (4) Inadequate planning, tidak membuat planning karena menganggap tidak penting, (5) Inexperience, kurang pengalaman. Inilah yang mendasari diperlukannya peran dari perguruan tinggi yang tidak hanya melakukan transfer pengetahuan, namun juga membangun mentalitas dari mahasiswa sebagai calon pengusaha untuk memiliki mental yang tangguh dalam berwirausaha. Oleh karena itu penting untuk mengetahui sejauh mana motivasi wirausaha dan mental wirausaha menjadi penting untuk mengukur minat wirausaha pada program studi mahasiswa kewirausahaan Universitas Brawijaya.

\section{Kajian Pustaka}

\section{Kewirausahaan}

Wirausaha merupakan orang yang mampu mengenali atau membuat produk baru, menentukan cara baru dalam proses produksi, menyusun operasi untuk pengadaan produk baru, memasarkannya serta mengatur permodalannya. Menurut Kamus Besar Bahasa Indonesia (KBBI), pengertian wirausaha sama dengan wiraswasta sesuai dengan pengertian yang telah dipaparkan. Schumpeter (1994) wirausaha adalah inovator: orang yang berkembang dengan ide dan mewujudkan ide tersebut ke dalam usaha yang memiliki pertumbuhan yang tinggi. Sedangkan Robbins \& Coulter (2010) kewirausahaan merupakan suatu proses suatu kelompok atau seseorang individu mengupayakan suatu hal dengan sebuah inovasi \& keunikan, tidak bergantung pada sumber daya yang digunakan pada saat ini. Hal tersebut sebagai upaya untuk membaca peluang dan menciptakan suatu nilai untuk memenuhi kebutuhan dan keinginan

Dalam membangun bisnis, tidak hanya dibutuhkan value creation. Kemampuan dalam memproduksi juga harus diperhatikan. Kompetensi dalam bisnis dapat berupa hal teknis maupun mental. Telaah Goleman (2006) mengemukakan bahwa kompetensi mental lebih berpengaruh dua kali lipat daripada kompetensi teknis memiliki terhadap kemajuan dan prestasi. Kompetensi teknis itu, misalnya sistem, governance, teknik, struktur, dan lain-lain. Kompetensi mentalitas di antaranya adalah values, belief, persepsi, mindset, ownership, kemampuan respons, dan lain-lain. Walaupun business leadership-nya tajam, jika tidak ada kompetensi mental untuk maju bertempur, maka akan kalah. 
Setelah values creation dan kompetensi dikuasai, maka dipastikan bahwa teknik produksi haruslah efisien. Di sini teknik dan manajemen berperan sangat penting dalam mencapai competitiveness atau daya saing. Dengan semakin pesatnya perkembangan teknologi, pasar tertutup tidak lagi relevan. Pasar bersifat terbuka dan borderless. Skala kompetisi meluas ke arah yang lebih luas. Tidak hanya lokal atau nasional, melainkan sudah regional yang menuju ke arah bisnis global.

Kemudian dibutuhkan mentalitas berani. Salah satu bentuk mentalitas berani adalah keberanian untuk bertindak segera ketika sebuah ide muncul. Tahap awal adalah mencatat ide tersebut tanpa melakukan penundaan sedikit pun. Banyak terobosan dan ide-ide yang terlintas ketika sedang beraktivitas harian, mengikuti kelas motivasi, atau mengikuti kegiatan yang lain. Kemunculan suatu ide harus mendapat tempat yang layak. Penundaan akan mengakibatkan kehilangan ide karena otak memiliki keterbatasan dalam menyimpan memori. Jikalau kita mampu mengingatnya kembali, jarang sekali kita dapat mengingatnya secara utuh.

Bisnis berarti outward looking. Ini menuntut sebuah kemampuan untuk melihat kebutuhan orang lain dan membuat seseorang merasa membutuhkannya padahal ia belum merasa butuh. Bisnis harus berani menerima kritik dan saran walaupun itu terasa menyakitkan, bukan hanya saran yang konstruktif melainkan juga kritik yang destruktif. Pelanggan yang memberikan tanggapan terhadap usaha kita masih menunjukkan kesetiaannya pada kita dan berharap pada kita untuk dapat melakukan perbaikan secara berkelanjutan.

Dalam suatu survei entrepreneurship yang diadakan Litbang Kompas, ditemukan bahwa $67 \%$ responden mengatakan amat tertarik untuk menjadi entrepreneur. Ketika ditanya apa alasan mereka tertarik, sebagian besar menjawab :

- Ingin berpenghasilan yang besar (30,7\%);

- Mandiri dan tidak diperintah orang lain (21,4\%); dan

- Tidak terikat jam kerja (21,15\%).

Semua alasan ketertarikan entrepreneurship tersebut, hanya berdasar pada self-centered, dengan kata lain masih memikirkan kepentingan diri sendiri. Dengan setting yang demikian, tidak perlu heran jika 8 dari 10 orang start up entrepreneurship mundur atau bangkrut hanya dalam satu semester setelah memulai bisnis.

Bisnis adalah pemenuhan solusi. Entrepreneurship atau bibit bisnis mulai tumbuh subur ketika seseorang berhenti untuk memperhatikan 
kebutuhan diri sendiri, dan mulai mengarahkan perhatian akan kesenangan dan kebutuhan orang lain. Kemudian menyandingkan kebutuhan tersebut dengan kompetensi dan bakat dari diri sendiri (Lim, 2012). Seseorang tidak akan berhasil dalam bisnis kalau masih self oriented, penyendiri, tidak tertarik dengan lingkungan sekitar. Pada mulanya orang tersebut mengira bisnisnya akan sukses, namun mungkin fakta akan berbeda. Orang lain tidak tertarik dengan produknya. Dengan kondisi ini amat sulit untuk memiliki insting bisnis, sejalan dengan apa yang dikatakan oleh Charles Darwin bahwa yang mampu bertahan itu bukanlah yang paling kuat, melainkan yang paling mampu beradaptasi dengan lingkungannya.

\section{Motivasi Wirausaha}

Menurut Sarosa (2005) motivasi merupakan dorongan dalam diri seseorang untuk melakukan sesuatu, misal menjadi young entrepreneur. Beberapa orang yang berhasil di dunia ini kebanyakan mereka yang memiliki motivasi yang kuat, sehingga ada suatu hal yang mendorong mereka untuk melakukan atau mencapai sesuatu. Oleh karena itu semakin kuatnya motivasi seseorang seringkali semakin tinggi peluang berhasil. Disitulah menunjukkan pentingnya motivasi dan pentingnya untuk me maintain motivasi dalams etiap tindakannya. Dalam penelitian Baum, Frese, and Baron (2007) mengungkapkan motivasi di dalam kewirausahaan terkait dengan capaian yang ingin diraih, seperti pengenalan dan peluang pasar. Motivasi bukan hanya untuk mencapai tujuan namun juga untuk mencari informasi terkait peluang berwirausahaa sehinggga dengan demikian bisa terbentuk kepercayaan diri dalam meraih semua hal tersebut.

\section{Mental Wirausaha}

Mahasiswa harus memiliki mental wirausaha, sehingga terbentuk karakter wirausaha yang melekat dalam diri seseorang dimana jiwa dan sikapnya selalu berorientasi pada kreatif dan inovatif. Sehingga terbentuk kepribadian percaya diri, yakin, optimis, penuh komitmen, berinisiatif, energik, berorientasi hasil, berwawasan ke depan, jiwa kepemimpinan, berani tampil beda, berani mengambil risiko dari perhitungan, dan siap dengan tantangan (Suharyono, 2012).

\section{Metodologi Penelitian}

Dalam penelitian ini termasuk ke dalam penelitian dasar dengan tujuan untuk menghasilkan pengetahuan untuk memahami sebuah fenomena (Sekaran, 2006). Berdasar pada rancangan penelitian, penelitian ini termasuk jenis explanatory research dengan pendekatan kuantitatif atau dengan kata lain terdapat variabel-variabel dalam penelitian yang kemudian 
membutuhkan uji statistik untuk melihat pengaruh antar variabel tersebut.

Populasi penelitian ini adalah mahasiswa aktif Program Studi Kewirausahaan Fakultas Ekonomi dan Bisnis Universitas Brawijaya. Teknik sampel yang digunakan adalah sampel jenuh atau total sampling dimana seluruh anggota populasi menjadi sampel penelitian.

Pengumpulan data menggunakan metode survei metode pengumpulan data primer yang diperoleh langsung dari sumber asli. Proses metode survei dengan cara membuat, menyebarkan, dan mengumpulkan kuesioner yang langsung dibagikan kepada responden. Adapun responden tersebut mengambil sampel dari satu populasi dan menggunakan kuesioner sebagai alat pengumpulan data (Masri dan Sofian, 1995).

Model hipotesis menunjukkan hubungan variabel Motivasi Wirausaha, Mental Wirausaha dan Minat Wirausaha. Variabel Motivasi Wirausaha dan Mental Wirausaha berperan sebagai construct eksogen yang juga dikenal dengan variabel independen yang tidak diprediksi oleh variabel lain. Variabel Minat Wirausaha berperan sebagai construct endogen yang diprediksi oleh variabel Motivasi Wirausaha dan Mental Wirausaha. Metode analisis data yang digunakan adalah Analisis Statistik Deskriptif dan Partial Least Square (PLS).

\section{Hasil Penelitian}

Jumlah mahasiswa aktif Program Studi Kewirausahaan tercatat 50 orang mahasiswa pada tahun masuk 2016, 59 orang mahasiswa pada tahun masuk 2017, dan 61 mahasiswa pada tahun masuk 2018. Dari angka tersebut diperoleh sampel sebanyak 170 orang responden dengan tingkat respon sebesar $87 \%$ atau 148 kuesioner yang kembali.

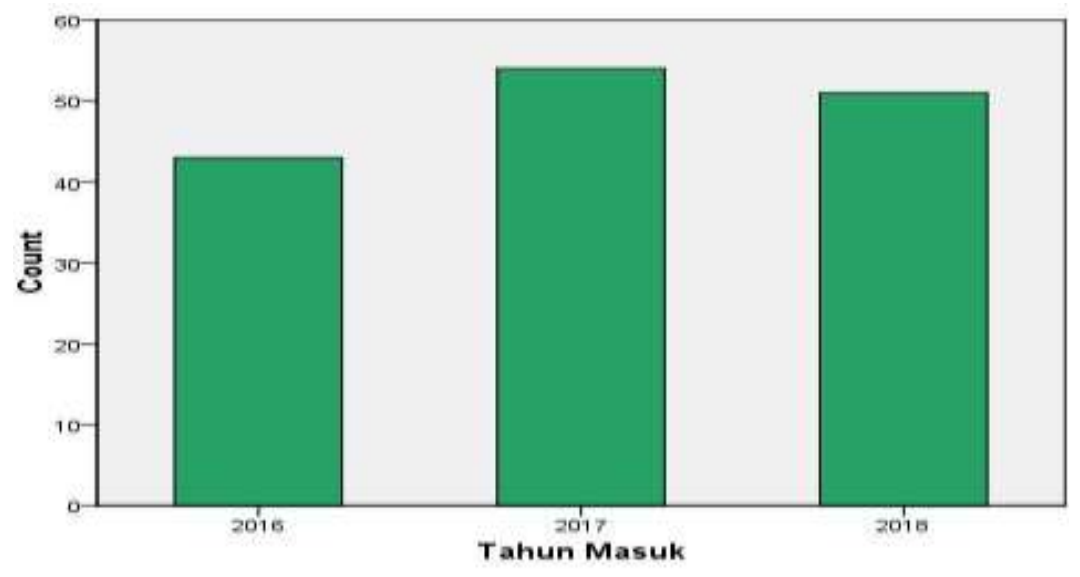

Gambar 1. Sebaran Responden Berdasarkan Tahun Masuk

78 | IQTISHODUNA Vol. 16 (1), 2020

http://ejournal.uin-malang.ac.id/index.php/ekonomi 
Gambar 1 menunjukkan sebaran responden berdasarkan tahun masuk. Pada gambar tersebut diketahui bahwa responden tertinggi adalah mahasiswa pada tahun masuk 2017 dengan jumlah 54 orang atau 36,5\%. Kemudian tahun masuk 2018 dengan jumlah 51 orang atau 34,5\%. Terendah adalah mahasiswa pada tahun masuk 2016 dengan jumlah 43 orang atau $29,1 \%$.

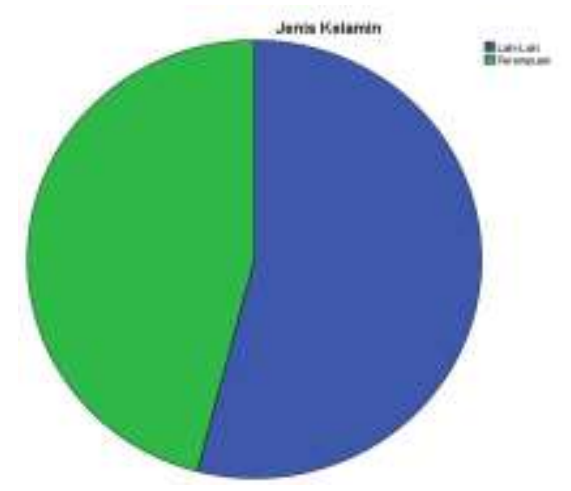

\section{Gambar 2. Sebaran Responden Berdasarkan Jenis Kelamin}

Gambar 2 menunjukkan sebaran responden berdasarkan jenis kelamin. Responden tertinggi adalah berjenis kelamin laki-laki yaitu sebanyak 80 orang atau 54,1\% kemudian perempuan sebanyak 68 orang atau 45,9\%.

Pada hasil confirmatory factor analysis (CFA) pada analisis Partial Least Square, loading factor memiliki suatu interpretasi. Loading factor adalah besar korelasi antara indikator dengan konstruk latennya. Pada penelitian sosial, pengukuran konstruk sangat sering dilakukan secara tidak langsung melalui indikator-indikatornya. Indikator dengan loading factor yang tinggi memiliki konstribusi yang tinggi untuk menjelaskan konstruk latennya.

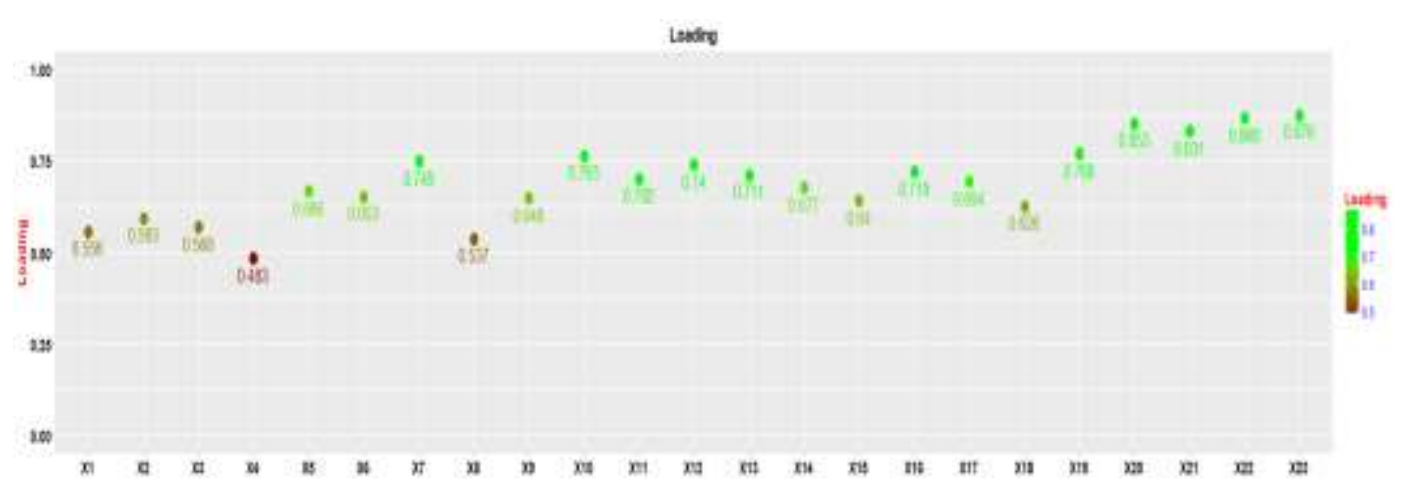

Gambar 3. Nilai Loading Untuk Setiap Indikator 
Pada sebagian besar referensi bobot faktor sebesar 0,50 atau lebih dianggap memiliki validasi yang cukup kuat untuk menjelaskan konstruk laten. Ferdinand (2000) menjelaskan bahwa loading faktor paling lemah yang bisa diterima adalah 0,40. Gambar 3 menjelaskan nilai loading dari setiap indikator telah memenuhi standar yang dipersyaratkan.

Nilai koefisien jalur Motivasi Wirausaha terhadap Mental Wirausha adalah 0,4975, yakni bernilai positif. Hal ini berarti Motivasi Wirausaha berpengaruh positif terhadap Mental Wirausaha. Diketahui dalam interval paths.perc.025 0.3642 dan paths.perc. 9750.6748 tidak memuat bilangan 0 , sehingga Motivasi Wirausaha berpengaruh signifikan terhadap Mental Wirausaha.

Nilai koefisien jalur pelayanan terhadap loyalitas adalah 0,3067 , yakni bernilai positif. Hal ini berarti pelayanan berpengaruh positif terhadap loyalitas. Diketahui dalam interval paths.perc.025 0.0101 dan paths.perc. 975 0.6006 tidak memuat bilangan 0 , sehingga pelayanan berpengaruh signifikan terhadap loyalitas.

Nilai koefisien jalur kepuasan terhadap loyalitas adalah 0,4038, yakni bernilai positif. Hal ini berarti kepuasan berpengaruh positif terhadap loyalitas. Diketahui dalam interval paths.perc.025 0.1225 dan paths.perc. 975 0.6952 tidak memuat bilangan 0 , sehingga kepuasan berpengaruh signifikan terhadap loyalitas.

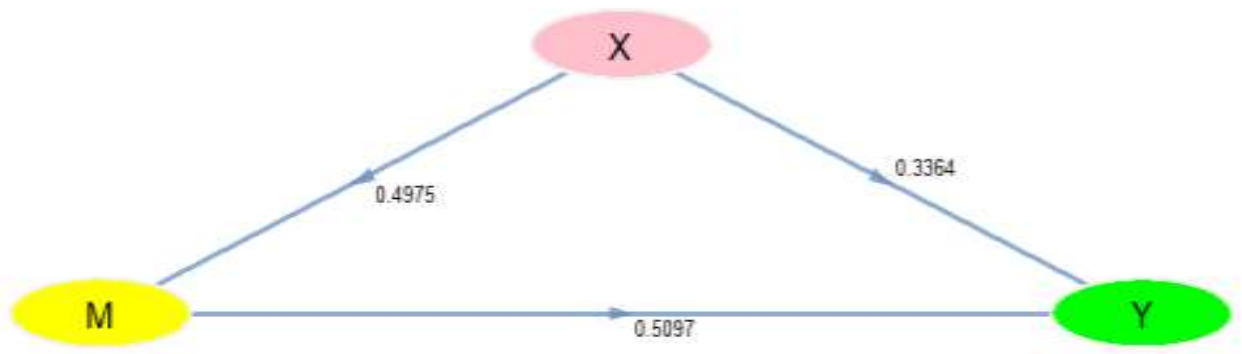

Gambar 4. Koefisien Jalur

Gambar 4. Menunjukkan besarnya koefisien jalur terhadap masingmasing variabel. Variabel eksogen terhadap variabel endogen memberikan nilai yang signifikan. Koefisien jalur variabel Motivasi Wirausaha terhadap Mental Wirausaha adalah 0,4975. Besarnya koefisien jalur variabel Motivasi Wirausaha terhadap Minat Wirausaha adalah 0,3364. Besarnya pengaruh variabel Mental Wirasuaha terhadap Minat Wirausaha adalah 0,5097. Dari hasil ini diketahui bahwa varibel Mental Wirausaha memediasi pengaruh 
variabel Motivasi Wirausaha terhadap variabel Minat Wirausaha. Hasil ini menjawab hipotesis 1 bahwa pengaruh motivasi wirausaha terhadap minat wirausaha signifikan dan hipotesis 2 bahwa pengaruh mental wirausaha terhadap minat wirausaha juga signifikan.

\section{Kesimpulan}

Motivasi wirausaha berpengaruh terhadap minat wirausaha pada mahasiswa Program Studi S1 Kewirausahaan Fakultas Ekonomi dan Bisnis Universitas Brawijaya. Mental wirausaha berpengaruh terhadap minat wirausaha pada mahasiswa Program Studi S1 Kewirausahaan Fakultas Ekonomi dan Bisnis Universitas Brawijaya.

\section{Daftar Pustaka}

Alma, B. (2007). Manajemen Pemasaran dan Pemasaran Jasa. Bandung: Alfabeta.

Baum, J. R., Frese, M., \& Baron, R. A. (2007). The psychology of entrepreneurship. Lawrence Erlbaum Associates. New Jersey: Mahwa.

Ferdinand, A. (2004). Metode Penelitian Manajemen: Pedoman Penelitian untuk Penulisan Skripsi, Tesis dan Disertasi. Semarang: UNDIP.

Goleman, D. (2006). Emotional Intelligence. Bantam Books.

https://kbbi.web.id/Kamus Besar Bahasa Indonesia (KBBI).

https://republika.co.id/berita/nfj64m50/iklim-wirausaha-RI-terburuk. Senin 24 Nov 2014.

Lim, Hendrik. (2012). Business Owner Mentality. Jakarta: Kompas Gramedia.

Masri, S., Sofian, E. (1995). Metode Penelitian Survei. Jakarta: PT Pustaka LP3ES Indonesia.

Robbins, S. P., Coulter, M. A. (2008). Management 10th Edition. New Jersey: Prentice Hall

Rokhimah., Margunani. (2017). Pengaruh Pendidikan Kewirausahaan dan Lingkungan keluarga Terhadap Jiwa Kewirausahaan. Economic Education Analysis Journal. Vol. 6 (2) Pp: 559-570. Journalhttp://journal.unnes.ac.id/sju/index.php/eeaj.

Sarosa, P. (2005). Kiat praktis membuka usaha. Becoming young entrepreneur: Dream big start small, act now. Panduan praktis \& motivasional bagi kaum muda dan mahasiswa. Jakarta: PT Elex Media Komputindo. 
Bayu Ilham Pradana, Rini Safitri

Schumpeter, J. A. (1994). Capitalism, Socialism and Democracy. Roudledge: Abingdon-on-Thames

Sekaran, U. (2006). Research Methods for Business, 4th Edition. Yon, Kwan Men (penerjemah). Metodologi Penelitian Bisnis. Edisi 4. Jakarta: Salemba Empat.

Suharyono (2012). Sikap Dan Perilaku Wirausahawan. Jurnal Ilmu dan Budaya. Vol. 40 (56) Pp: 6551-6586. 